These spectroscopies are element specific, bulk sensitive probes of unoccupied and occupied valence electronic states. Glycine is the simplest form of the amino acid that has a hydrogen atom as an organic substituent. We discuss $\mathrm{pH}$ dependence of the electronic structure associated with the ionization of amino and carboxylate groups and their effects on hydration. The XAS and XES measurements were done at the beamline BL17SU SPring-8 using a newly developed experimental system[1] for the study of the electronic structure of liquid systems. We used $\mathrm{O}$ 1s edge excitation to contrast the effect of ionization of the carboxylate group with other effects. Glycine solutions were prepared by dissolving glycine using Ultra pure water to create a $2 \mathrm{M}$ glycine solution. The solution was circulated outside the vacuum at room temperature. [1] T. Tokushima and Y. Harada et al. Rev. Sci Instrum. 77 (2006) 063107.

\section{P-113 ホタルルシフェラーゼによる生物的ジオキセタノン分解過程：ア} ニオン化から複数の発光励起状態生成物まで

Biological decomposition processes of firefly dioxetanone by luciferase: From anionization to plural fluorescent excited state products.

Hironori Sakai (1), Naohisa Wada (1) and Masami Kusunoki (2). (1: Dept of Life Sciences, Toyo University; 2: Dept of Physics, Meiji University

Firefly luciferase (Luc) catalyses oxidation of luciferyl-adenylate, which is produced from luciferin (D-LH2) and ATP in the presence of $\mathrm{Mg}^{2+}$. Recently, Akiyama's group showed that this reaction likely produce 3 luminous excited states of oxyluciferin (Oxyln") with a total quantum yield of $\sim 41 \%$. This study appears to be in line with our previous finding (JBS45) that decomposition of labile intermediate R1, i.e. a deprotonated dioxetanone ( $\mathrm{DOX}^{-}$), can form new intermediates, $\mathrm{R} 2$ and $\mathrm{R} 3$, corresponding to the $\mathrm{O}-\mathrm{O}$ bond breaking in $\mathrm{R} 1$ and the $\mathrm{CO}_{2}$ twisting around an elongated $\mathrm{C} 4-\mathrm{C}\left(\mathrm{O}_{2}\right)$ bond in $\mathrm{R} 3$, when it put in the hydrophobic pocket of Luc surrounded by protonated AMP and H247, and charged amino acids nearby, which modeled according to Genji-botaru Luc's (Nakatsu et al, Nature06). Using TD-DFT/B3LYP/6-31+G* method, we ascertained that the energy diff between R2 and R3 states is a little bit larger than main fluor energies of R3*-to-R3, concluding that R2 would slowly and hence efficiently relax to some luminous excited states similar to $\mathrm{R} 3{ }^{*} \mathrm{~s}$. And, we report the $V(b, \psi)$ surface to locate these luminous states.

3P-114 3 次元 RISM 理論による溶媒中の B-DNA の構造最適化

Optimization of structure of B-DNA in solution by 3D-RISM Theory

Yutaka Maruyama and Fumio Hirata. (Dept Theoretical and Computational Molecular Science, Institute for Molecular Science)

We performed the optimization of the structure of B-DNA in solution byusing the Quasi-Newton method combined with the three-dimensional referenceinteraction site model (3D-RISM)theory, which is a statistical mechanical theory describingthe three-dimensional solvation structure around solute molecule aswell as the solvation free energy.

The initial structure of B-form DNA d(5'CGCGAATTCGCG3') was taken from the Brookhaven Protein Data Bank (PDB). We used theforce field parameters of AMBER param99 for the calculation. We performed the optimizations in vacuo in water. The result in vacuo show that DNA cannot keep double helicalstructure without solvent.On the other hand the optimized structure of DNA in water keeps the doublehelixB-form. These results indicate that solvation environment plays anessential role to keep the DNA structure. The root mean square distance (RMSD) betweenthe optimized and initial structures is $0.55 \mathrm{AA}(0.52 \mathrm{AA}$ without hydrogens), but the totalenergy of the optimized structure (Total: -4988.5, Conformational:901.4, Solvation: $-5889.9 \mathrm{kcal} / \mathrm{mol}$ ) is about $440 \mathrm{kcal} / \mathrm{mol}$ lowe than the initial's one (Total: -4543.7 ,Conformational: 1353.6, Solvation: -5897.3 $\mathrm{kcal} / \mathrm{mol}$ ). Then it isnecessary to Optimize the solute structure.

The characteristic hydration pattern for DNA (so called 'spinehydration') along the minor groove is in good agreement with the experimental one.

\section{$3 \mathrm{P}-115$ 溶質近傍のハイパーモバイル水に関する理論解析}

A theoretical analysis on the hyper-mobile water molecules near a solute

Masahiro Kinoshita (1) and Makoto Suzuki (2). (1: Institute of Advanced Energy, Kyoto University; 2: Graduate School of Engineering, Tohoku University

In connection with the experimental observation that the hyper-mobile water is induced around F-actin, we calculate physically insightful components of the rotational entropy of hydration of a solute using the angle-dependent integral equation theory combined with the multipolar water model. We also analyze the contribution from the water molecules within $[\mathrm{r}, \mathrm{r}+$ deltar $]$ to each component.The rotational freedom (RF) of water molecules near a nonpolar solute is lowered due to enhanced hydrogen bonding. The water structure near a charged solute is perturbed and the perturbation becomes larger as the charge increases. Next to a solute with a sufficiently large surface charge density, water molecules are tightly restrained. In either case, the water molecules with low RF are primarily those in contact with the solute surface. In cases of charged solutes, the regions of restrained RF and of enhanced RF appear alternately near the solute. There are certainly the regions within which the RF of water molecules is much higher than in the bulk. As the surface charge density increases, such regions become slightly farther from the solute with further enhanced RF, and they become longer-ranged for larger solutes.Since F-actin is large and rich in negative surface charges, it should experimentally be observed that the water molecules with lowered rotational mobility (RM) are primarily those in contact with the surface while the water molecules with higher RM (i.e., hyper-mobile water molecules) are more outside.

\section{P-116 蛋白質動力学転移における水和水の構造とダイナミクス}

Structure and dynamics of the protein hydration water at the protein dynamical transition

Hiroshi Nakagawa (1), Yasumasa Joti (2), Akio Kitao (2) and Mikio Kataoka (1,3). 1:Quantum Beam Science Directorate, Japan Atomic Energy Agency: 2:Laboratory of Molecular Design, Institute of Molecular and Cellutar Biosciences, University of Tokyo 3: Graduate School Materials Science, Nara Institute of Science and Technology)

Most globular proteins work in an aqueous milieu and water molecules located at the protein surface strongly affects the protein stability and function. Structure and dynamics of hydration water on the protein, staphylococcal nuclease, were examined at various hydration levels to study the hydration effect on dynamics. We found that the hydration dependent protein dynamical transition around $240 \mathrm{~K}$ shows the threshold hydration level between 0.30 and 0.42 ( $\mathrm{g}$ water/g protein). Below the threshold, hydration water is localized to form several independent clusters on the surface, while above the threshold level the hydration water encircles the protein via hydrogen bond, suggesting the percolation transition. The MD simulations at various hydration indicate that the size of the cluster of hydrogen bonded hydration water dramatically increased above the threshold level of the hydration level. We concluded that the dynamics of hydration water is coupled with the protein dynamics via hydrogen-bond network on the protein-water interface. Such a dynamical coupling drives the hydration dependent protein dynamical transition.

\section{P-117 リゾチーム周辺における水分子の流れパターン（順流、渦流、} Dry/Wet 流れ）に関する分子動力学シミュレーションによる解析

Fair current, vortex, and drying/wetting water flow around lysozyme investigated by molecular dynamics simulation

Koji Umezawa(1), Ryota Morikawa(2), Haruki Nakamura(3), and Junichi Higo(4). (1 Graduate School of Frontier Biosciences, Osaka University; 2:School of Life Sciences, Tokyo University of Pharmacy and Life Sciences: 3:Institute for Protein Research Osaka University; 4:The Center for Advanced Medical Engineering and Informatics, Osaka University)

Previously, we studied the translational motion of water molecules around a protein by molecular dynamics simulation, and we show that the water molecules collectively flow and the flows exhibit three notable patterns (fair current, vortex, and drying). In the current study, we quantitatively investigated the flow patterns around human lysozyme in the equilibrium state at room temperature. From the result, we find that the frequency of appearance of the flow patterns depends on surface regions of the protein. There is the region where the flow frequently occurs near the protein. This region is located around the ligand-binding cleft of lysozyme. We studied a relationship among the flow patterns. Near the protein surface, the drying flow correlates with the fair current running away from the protein, while the wetting flow does with the fair current running toward the protein. It suggests that the water flow may be related to an interaction mechanism between a ligand and the receptor protein. Thus, the water flow should be important from this new view point for understanding a molecular interaction mechanism.

\section{P-118 誘電緩和スペクトル測定によるATP 加水分解反応の水和解析}

Hydration change in ATP hydrolysis system as measured by dielectric spectroscopy

George Mogami (1,2), Takao Kodama (3), Makoto Suzuki (1,2). (1:Dept. of Materials Processing, Graduate School of Engineering Tohoku University. 2:CREST, Japan Science and Technology Agency; 3:Dept, of Bioscience and Bioinformatics, Faculty of Computer Science and Systems Engineering, Kyusyu Institute of Technology)

Of various unsettled issues of fundamental importance in biological science is the molecular origin of a large negative Gibbs energy change $\left(\Delta_{\text {hyd }} G^{\circ}<0\right)$ for hydrolysis of ATP into ADP and inorganic phosphate (Pi). George et al. (BBA 223:1,70) proposed that the very difference in the hydration energy between the reactants (ATP $+\mathrm{H}_{2} \mathrm{O}$ ) and products (ADP $+\mathrm{Pi}$ ) would principally contribute to the $\Delta_{\text {hyd }} G^{\circ}$. This theory seems reasonable but requires experimental verification. The first step to tackle this challenging issue is to quantitatively clarify the hydration states of ATP, ADP and Pi. Toward this end, a high-resolution microwave dielectric spectroscopy is a promising method, which has been recently applied to aqueous solutions of alkali metal halides for the purpose of studying the state of water surrounding ions (Miyazaki et al., J Phys Chem, submitted). Solutions were prepared by dissolving the $\mathrm{Na}_{2} \sim$ salt of each $\mathrm{ATP}$, ADP and $\mathrm{Pi}$ and adjusting $\mathrm{pH}$ to $8.0(>\mathrm{pK}+1)$ by the addition of $\mathrm{NaOH}$ so as to contain almost fully $(>95 \%)$ dissociated forms $\left(\mathrm{ATP}^{4-}, \mathrm{ADP}^{3-}\right.$ and $\left.\mathrm{HPO}_{4}{ }^{2-}\right)$. Measurements were then made in a conically shaped glass cell (total volume, 3.2 $\mathrm{ml}$ ) connected to a microwave network analyzer (Agilent) at $20 \pm 0.01^{\circ} \mathrm{C}$ with pure water as the reference. The spectra thus obtained were qualitatively similar to those for other salt solutions. The analysis is under way to calculate the volume fraction $\phi$, relaxation frequency $f_{c}$ and dielectric dispersion intensity $\delta$ of hydrated solutes.

\section{P-119 分子動力学と量子化学計算による水和ダイナミクス研究}

Investigation of hydrating water dynamics through MD and QM

\section{Takuya TAKAHASHI and Tomoki SHIOMI (College of Life Sciences, Ritsumeikan Univ)}

During enzymatic reaction such as ATP hydrolysis, the inner structure of enzyme proteins and the physico-chemical property of the water molecules on the protein surface are supposed to change. Here, an important issue is whether widely used models for water and solute molecules are applicable to predict the dynamics and 